\title{
Correction to: Molecular biomarker responses in the freshwater mussel Anodonta anatina exposed to an industrial wastewater effluent
}

\author{
Gustaf M. O. Ekelund Ugge $^{1,2}$ (D) Annie Jonsson ${ }^{2} \cdot$ Olof Berglund $^{1}$ \\ Published online: 7 September 2021 \\ (C) Springer-Verlag GmbH Germany, part of Springer Nature 2021
}

Correction to: Environmental Science and Pollution Research https://doi.org/10.1007/s11356-021-15633-4

The layout of Table 2 contains missing line brakes that make the table confusing to read.

The original article has been corrected.

Publisher's note Springer Nature remains neutral with regard to jurisdictional claims in published maps and institutional affiliations.

The online version of the original article can be found at https://doi.org/ $10.1007 / \mathrm{s} 11356-021-15633-4$

Gustaf M. O. Ekelund Ugge

gustaf.ekelund_ugge@biol.lu.se

1 Department of Biology, Lund University, Sölvegatan 37, 223

62 Lund, Sweden

2 School of Bioscience, University of Skövde, Högskolevägen 3, 541 46 Skövde, Sweden 